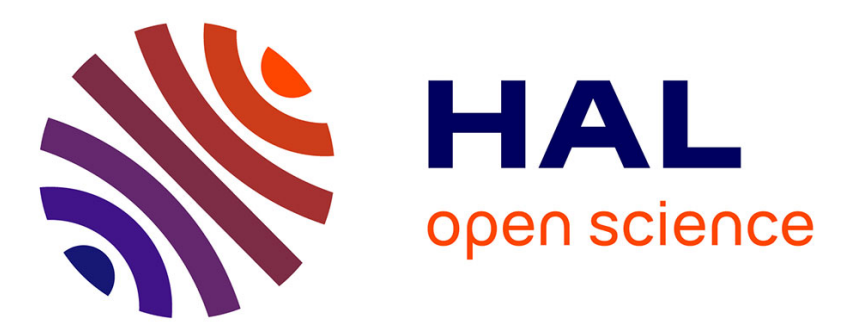

\title{
A spatialising tool to simulate pesticide fate in the unsaturated zone on a catchment scale
}

Alessandro Esposito, Costantino Vischetti, Giuseppe Errera, Marco Trevisan, Luciano Scarponi, Michael Herbst, Michael Ciocanaru, Harry Vereecken

\section{- To cite this version:}

Alessandro Esposito, Costantino Vischetti, Giuseppe Errera, Marco Trevisan, Luciano Scarponi, et al.. A spatialising tool to simulate pesticide fate in the unsaturated zone on a catchment scale. Agronomy for Sustainable Development, 2005, 25 (2), pp.279-283. hal-00886268

\section{HAL Id: hal-00886268 https://hal.science/hal-00886268}

Submitted on 1 Jan 2005

HAL is a multi-disciplinary open access archive for the deposit and dissemination of scientific research documents, whether they are published or not. The documents may come from teaching and research institutions in France or abroad, or from public or private research centers.
L'archive ouverte pluridisciplinaire HAL, est destinée au dépôt et à la diffusion de documents scientifiques de niveau recherche, publiés ou non, émanant des établissements d'enseignement et de recherche français ou étrangers, des laboratoires publics ou privés. 


\title{
A spatialising tool to simulate pesticide fate in the unsaturated zone on a catchment scale
}

\author{
Alessandro ESPOSITO ${ }^{a *}$, Costantino VISCHETTI $^{\mathrm{b}}$, Giuseppe ERRERA ${ }^{\mathrm{c}}$, Marco TREVISAN ${ }^{\mathrm{c}}$, Luciano SCARPONI ${ }^{\mathrm{d}}$, \\ Michael HERBST ${ }^{\mathrm{e}}$, Michael CIOCANARU ${ }^{\mathrm{e}}$, Harry VEREECKEN ${ }^{\mathrm{e}}$ \\ a ISAFOM CNR, Sezione Olivicoltura, Via Madonna Alta 128, 06128 Perugia, Italy \\ b Dipartimento Biotecnologie Agrarie ed Ambientali dell'Università, Ancona, Italy \\ ${ }^{\mathrm{c}}$ Istituto Chimica Agraria e Ambientale, Università Cattolica del Sacro Cuore, Piacenza, Italy \\ ${ }^{\mathrm{d}}$ DISAPROV, Sez. Chimica Agraria, Università di Perugia, Italy \\ ${ }^{\mathrm{e}}$ Forschungszentrum Jülich, ICG IV, Institut für Agrosphäre, Germany
}

(Accepted 11 May 2004)

\begin{abstract}
A tool has been designed to calculate the leaching potential of pesticide on a catchment scale using the one-dimensional pesticide leaching model MACRO. The tool is able to collect the input data of the study area in a grid with homogeneous cells and prepare spatially distributed data required by MACRO. Successively, the tool can run multiple MACRO simulations for each cell of the grid and organise output reports following the user's preference, as well as generate output files compatible with GIS and other environmental software applications. The tool was tested to simulate the behaviour in the unsaturated zone of water and pesticide isoproturon used on winter wheat at $1.75 \mathrm{~kg}^{-1}$ of active ingredient in a German study area for 10 years of meteorological data and for different crop-soil combinations. Maps of isoproturon concentration in the liquid phase were created using the spatialised output data from the tool.
\end{abstract}

MACRO / leaching / isoproturon / catchment

\section{INTRODUCTION}

Potential groundwater contamination may be defined as the possibility that a given fraction of pesticide application reaches the water table, the effective contamination depending on the meteorological conditions following the application data. The measurement of pesticide concentrations in groundwater is laborious and costly (Cohen et al., 1984; Weber and Miller, 1989); this is why in recent years a number of Pesticide Fate Models (PFMs) have been developed to predict the fate of pesticides in soil and water (FOCUS, 1995). These models have been standardised as regards the registration procedures of new chemicals, the screening tests for pesticide selection in different pedo-climatic conditions and the implementation of Geographic Information Systems. Groundwater vulnerability to contamination depends on the various physical, chemical and biological processes that determine the environmental fate of pesticide. The rate and importance of each of these processes are strongly affected by various space- and time-dependent environmental factors (soil, weather and crop) and the properties of the pesticide itself. For this reason spatialisation of
1D models is needed in order to simulate the behaviour of pesticide on a regional scale, taking into account the spatial variability of some parameters. Some experiments on this issue are reported in the literature (Tiktak et al., 2002). In the European Project PEGASE (Pesticides in European Groundwaters: detailed study of representative Aquifers and Simulation of possible Evolution scenarios) a strategy to simulate contaminants' fate in the unsaturated and saturated zones is under development (Mouvet et al., 2001). In this area our group is mainly involved in the development of tools dedicated to the modelling of pesticide fate from the topsoil compartment up to and into the aquifer.

The paper refers to the realisation of a computerized tool which allows the simulation of pesticide fate in the unsaturated zone on a catchment scale. To obtain this, the spatialisation of the $1 \mathrm{D}$ unsaturated zone model MACRO was carried out, and the final product should be able to simulate the spatial-variable movement of pesticides in the unsaturated zone. This tool was used to simulate the behaviour of water and the pesticide isoproturon in a German catchment.

* Corresponding author: alessandro.esposito@iro.pg.cnr.it 

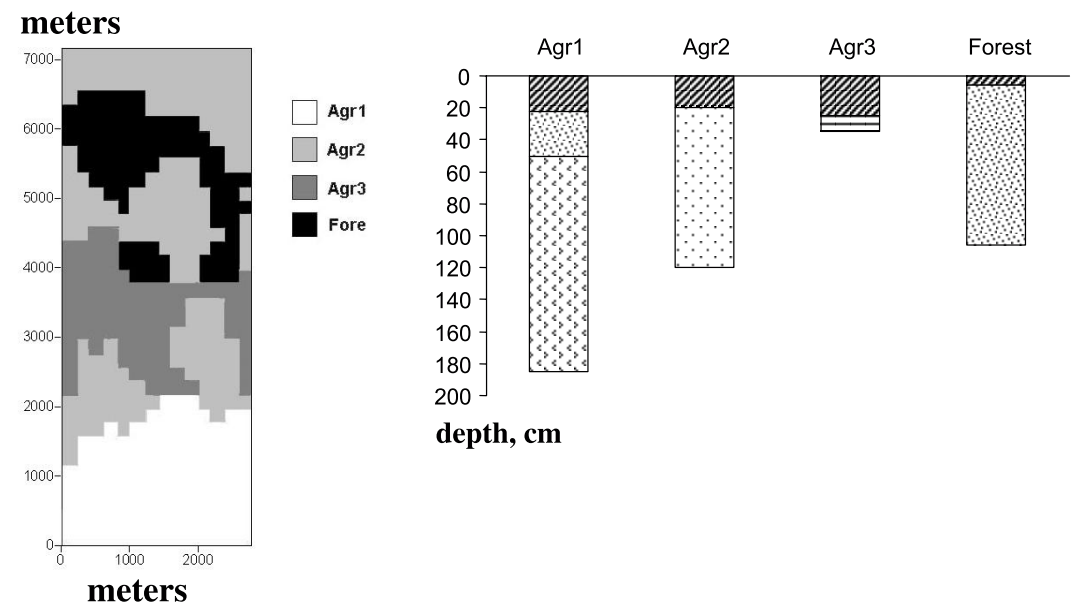

Figure 1. Spatial distribution and horizon depth of the four representative soil profiles.

\section{MATERIALS AND METHODS}

\subsection{Model}

MACRO is a physically-based preferential flow model that can be used to describe water and solute transport in a variety of soil types. The total soil porosity is divided into two flow domains (macropores and micropores), each characterised by a flow rate and solute concentration (Jarvis, 1994). Crop development is based on a simple model which uses dates for emergence, maximum leaf area and harvest. Pesticide degradation is modelled using first-order kinetics. Degradation half-lives need to be specified for the solid and liquid phases of the macropores and micropores, and may be adjusted for temperature and moisture effects. Sorption is assumed to be at instantaneous equilibrium and to be described by a Freundlich isotherm. MACRO was selected because of its wide diffusion as a validated model useful for pesticide fate simulation in the unsaturated zone (Jarvis et al., 1995; Besien et al., 1997; Larsson et al., 1999) and is one of the four models selected by the EU for pesticide registration procedures (FOCUS, 1995). MACRO Version 4.3 was used for the current paper.

\subsection{Tool}

A tool was created using the data sheet MS Excel with the programming language Visual Basic for Application. It is structured in a series of MS Excel sheets in which the user can easily input the scenario data required by MACRO. Each scenario can contain at the most 65500 cells.

The tool is able to do the following: divide the study area into a grid with homogeneous cells, prepare spatially distributed data required by MACRO, and prepare MACRO input data files for each cell of the grid. Successively, the tool can run multiple MACRO simulations for each cell of the grid and organise output reports following the user's preference as well as
Table I. Main properties of the four soil horizons considered in the study.

\begin{tabular}{lccccc}
\hline soil & $\begin{array}{c}\text { horizon } \\
\mathrm{cm}\end{array}$ & $\begin{array}{c}\text { sand } \\
\%\end{array}$ & $\begin{array}{c}\text { clay } \\
\%\end{array}$ & $\begin{array}{c}\mathrm{C} \text { org. } \\
\%\end{array}$ & $\begin{array}{c}\mathrm{Ks} \\
\mathrm{mm} \mathrm{h}^{1}\end{array}$ \\
\hline Forest & $0-6$ & 9.5 & 12 & 4.24 & 3.08 \\
& $6-100$ & 43.5 & 19 & 0.20 & 7.00 \\
Agr1 & $0-22.5$ & 10.5 & 11 & 1.70 & 3.33 \\
& $22.5-50$ & 11.5 & 10 & 0.80 & 1.33 \\
& $50-185$ & 12.5 & 21 & 0.10 & 0.71 \\
Agr2 & $0-20$ & 8.5 & 13 & 2.30 & 2.04 \\
& $20-120$ & 43.5 & 19 & 0.20 & 4.58 \\
Agr3 & $0-25$ & 60 & 14 & 1.20 & 57.33 \\
& $25-35$ & 66.5 & 10 & 0.20 & 37.13 \\
\hline
\end{tabular}

generate output files compatible with GIS and other environmental software applications.

\subsection{Site}

The Zwischenscholle test area is a $25-\mathrm{km}^{2}$ field located in Jülich, North Rhine - Westfalia (Germany). The area is characterised by forest and agricultural land use. A grid was established over the field using cells $200 \mathrm{~m} \times 200 \mathrm{~m}$, with a total of 14 columns and 36 rows. The soil consists of a variable horizon of Pseudogley followed by alternate layers of gravel and sand. A schematic subdivision of areas into four types of soil was done for simulation purposes. The spatial distribution of the four soils is shown in Figure 1, while in Table I the main properties of the four soil horizons are reported.

The main crop is sugar beet with an annual turning of winter wheat, winter barley and winter rye. An estimated fraction of 
crop distribution was used for the calculation of the random spatial distribution. This distribution was used for the modelling procedure, creating a map of distribution for each year of the simulation.

\subsection{Modelling exercise}

The modelling exercise was conducted for the unsaturated zone. The tool linked with the MACRO model was used to simulate the behaviour of water and the pesticide isoproturon used on winter wheat at $1.75 \mathrm{~kg} \mathrm{ha}^{-1}$ of active ingredient in the Zwischenscholle site for 10 years of meteorological data and for each crop-soil combination. Simulations were performed for the first $2 \mathrm{~m}$ of the soil profile. Three representative cells of the grid (one point for each soil type) were identified to test the water and pesticide simulations.

\section{RESULT AND DISCUSSION}

The spatial schematisation approach used is a modification of the "unique combination" technique described by Tiktak et al. (1996). During the first step, the simulated area was divided into a grid of homogeneous cells (raster representation). Then the scenario parameters were divided into an adequate number of classes to represent the variability of the entire area. The classes refer mainly to soil physical properties, soil profiles, land use and crop rotation. Therefore, the appropriate class number was attributed to every cell reproducing a series of map layers. Moreover, a series of map layers was produced for each year of simulation to consider crop rotation, since MACRO can simulate one crop at a time. At the end, a combination of classes for every cell is obtained, overlapping the different map layers, and all the cells identified by the same combination are "unique combination". The spatialising tool uses a series of MS Excel sheets in which all the data for the simulations have to be stored to form a database.

The tool starts to work with a series of thematic sheets to be filled with the data requested by MACRO. The first step is the definition of the dimension of the scenario, specifying the number of cells and the name of the scenario. Afterwards, the program defines the unique identification (ID cells) for each cell and inserts these data in each successive sheet. The second thematic sheet includes data for georeferencing the cells: for each cell latitude, longitude and altitude a.s.l. need to be specified. The following sheets request the input for MACRO, starting with SWITCHES which represent the user options, specifying what to include or not in the simulation (i.e. irrigation, drains etc.). Switches are divided into two categories: fixed (i.e. not modifiable) and modifiable. The program then presents a series of Excel sheets where the input parameters requested by MACRO have to be inserted. When all input parameters have been inserted, and the worksheets saved with specific names, the program comes back to the initial sheet and the option "Create MACRO input files" is selected, which creates MACRO input files. This operation is automatically performed by the program. Each file refers to a single cell of the grid and each has a specific name corresponding to the ID of the cell.

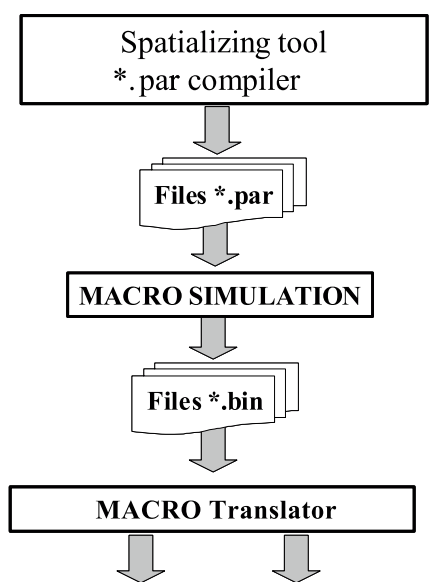

Generate maps and/or aquifer model input files

Figure 2. Flow diagram of spatialising tool.

Successively, the tool manages the class attribution, the unique-combination computation and the preparation of parameter files (*.PAR) for the model. After the input file compilation MACRO executes all the simulations in batch mode. To start simulations the option "RUN MACRO" in the initial sheet must be selected. The program will manage the MACRO runs for each cell of the grid. After all the simulations have been completed, the option "Extract output data" in the initial sheet must be selected, which can extract from different output files. This operation activates a routine which extracts data from the output files of each cell of the grid. The extracted data refer to: (i) total water content (micropore and macropore); (ii) water flow rate out of layer from macropores; (iii) water flow rate out of layer from micropores; (iv) total water storage in micropores in the whole profile $(\mathrm{mm})$; $(\mathrm{v})$ total water storage in macropores in the whole profile (mm); (vi) total accumulated percolation $(\mathrm{mm})$; (vii) solute flow rate out of layer (micropores - mass $\times$ $\mathrm{m}^{2} / \mathrm{h}$ ); (viii) solute flow rate out of layer (macropores - mass $\times$ $\mathrm{m}^{2} / \mathrm{h}$ ); (ix) accumulated solute leaching (total for macro- and micropores) (mass $/ \mathrm{m}^{2}$ ), and (x) accumulated amount of solute lost in runoff (mass $\left./ \mathrm{m}^{2}\right)$.

At this point the tool assigns the results to every cell, storing the results in a series of binary files (*.BIN), and creates a plot file (MACRO Translator) useful for generating plot maps and/ or supplying input to 3D saturated-zone models. The flow diagram of the spatialising tool is described in Figure 2. The tool described here was used to perform a simulation exercise in the Zwischenscholle site.

In Figure 3 hydrological balances for three representative points of the grid for the ten years of simulation are reported for the cropped soil profile. As can be seen, data are similar for the three soil types. Actual Evapo-Transpiration (AET) was $4205 \mathrm{~mm}$ in Agr1, $4235 \mathrm{~mm}$ in Agr2 and $4153 \mathrm{~mm}$ in Agr3, while leaching below $5 \mathrm{~m}$ depth was $3084 \mathrm{~mm}$ in Agr1, 2588 in Agr 2 and 3027 in Agr 3. 

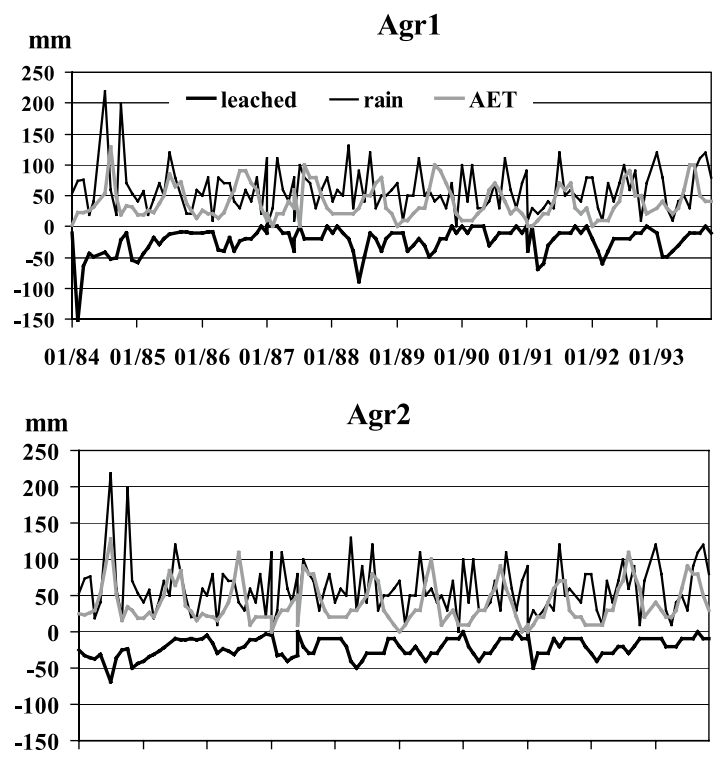

01/84 01/85 01/86 01/87 01/88 $01 / 8901 / 90 \quad 01 / 91 \quad 01 / 92 \quad 01 / 93$

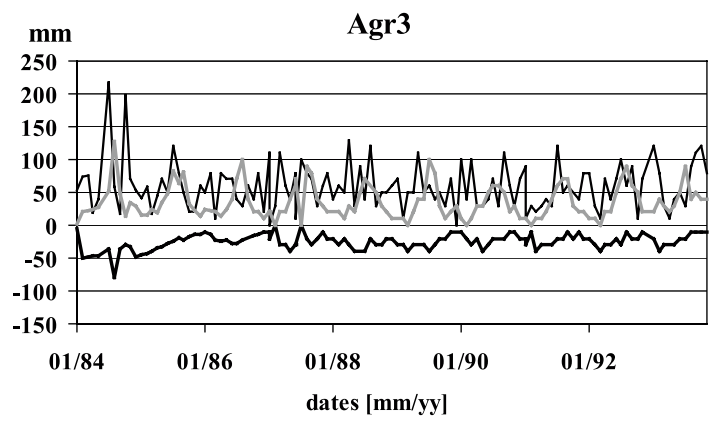

Figure 3. Hydrological balances for three representative points of the grid for the ten years of simulation. AET = Actual Evapo-Transpiration.

The time series of isoproturon at $0.5 \mathrm{~m}$ depth for three points of the map is shown in Figure 4. As can be seen, peaks of concentration are strictly near the date of treatment and the movement was more pronounced in soil 3, where gravel is present under $30 \mathrm{~cm}$ depth and pesticide and water can move easily and rapidly.

Maps of isoproturon concentration $\left(\mu \mathrm{g} \mathrm{L}^{-1}\right)$ in the liquid phase at $1 \mathrm{~m}$ depth after 1 and 5 years are reported in Figure 5. The maps of concentration obtained show that only a small proportion of the pesticide applied reaches $1 \mathrm{~m}$ depth and suggest that the actual hazard for groundwater contamination is very small in the case studied. However, depending on soil profile depth and composition, the movement of pesticide shows noticeable differences in different points of the map.

In conclusion, in this preliminary work the tool created showed a good reliability in spatialising data and in managing input/output data. This aspect is important to handle data flux between MACRO and 3D aquifer models and it allows one to perform simulations in the unsaturated/saturated zone on a regional scale.
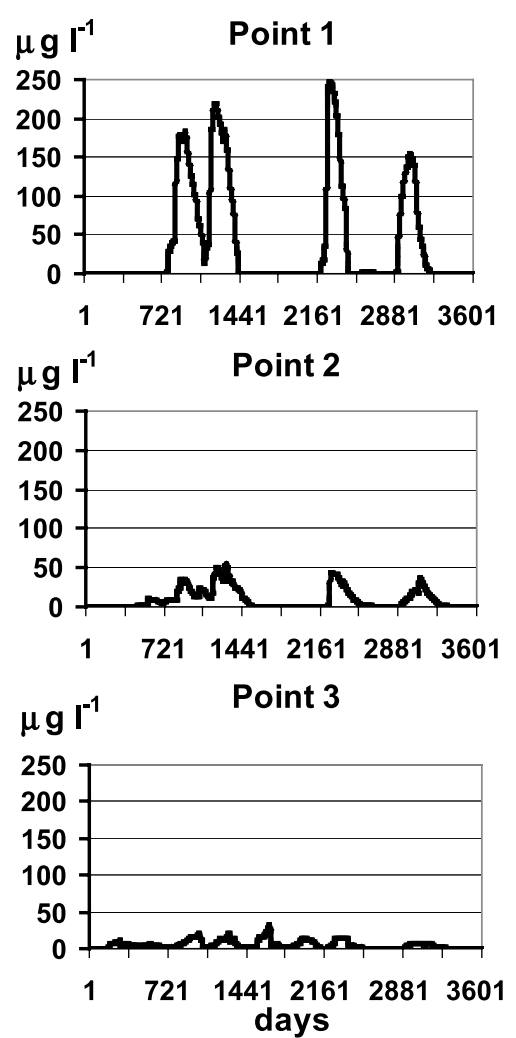

Figure 4. Time series of isoproturon concentration at $0.5 \mathrm{~m}$ depth for three representative cells of the grid.
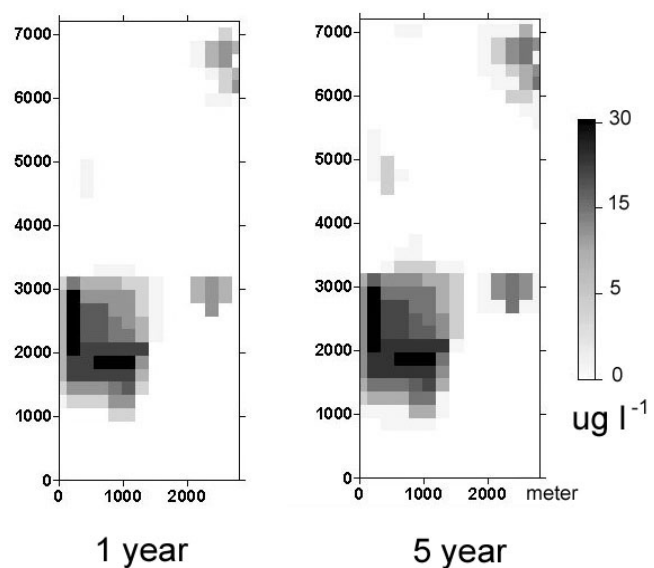

Figure 5. Concentration maps of isoproturon $\left(\mu \mathrm{g} \mathrm{L}^{-1}\right)$ at $1 \mathrm{~m}$ depth in the entire area considered at 1 and 5 years of simulation.

Acknowledgement: This research was funded by the EU project PEGASE (Pesticides in European Groundwaters: detailed study of representative Aquifers and Simulation of possible Evolution scenarios); Contract number: EVK1CT1999-00028. 


\section{REFERENCES}

Besien T.J., Jarvis N.J., Williams R.J. (1997) Simulation of water movement and isoproturon behaviour in a heavy clay soil using the MACRO model, Hydrol. Earth Syst. Sci. 1, 835-844.

Cohen S.Z., Creeger S.M., Carsel R.F., Enfield C.G. (1984) Potential groundwater contamination from agricultural pesticides, in: Kruegar R.F., Seiber J.N. (Eds.), Treatment and disposal of pesticide wastes, ACS Symposium Series 259, American Chemical Society, Washington DC, pp. 298-325.

FOCUS (FOrum for the Co-ordination of pesticide fate models and their Use) (1995) European scenarios for leaching models, in: Leaching Models and EU Registration, The final report of the work of the Regulatory Modelling Work group of FOCUS, Doc 4952/VI/95, 5 , 1995 , pp. 55-75.

Jarvis N.J. (1994) The MACRO model (Version 3.1): Technical description and sample simulations. Reports and Dissertations No. 19, Department of Soil Sciences, Swedish University of Agricultural Sciences, Uppsala, $51 \mathrm{p}$.

Jarvis N.J., Larsson M., Fogg P., Carter A.D. (1995) Validation of the dual-porosity model MACRO for assessing pesticide fate and mobility in soil, in: Walker A., Allen R., Bailey S.W., Blair A.M., Brown C.D., Günther P., Leake C.R., Nicholls P.H. (Eds.), Pro- ceedings of the BCPC Symposium "Pesticide movement to water", Warwick, pp. 161-170.

Larsson M.H., Jarvis N.J. (1999) Evaluation of a dual-porosity model to predict field-scale solute transport in a macroporous clay soil, J. Hydrol. 215, 153-171.

Mouvet C., Golaz C., Thiery D., Baran N.,., Ritsema C., Normand B., Vischetti C., Nitzsche O. (2001) Pesticides in European Groundwaters: detailed study of representative Aquifers and Simulation of possible Evolution scenarios (PEGASE), Proceedings of ETCA meeting in Harrogate, UK, May 21-23, 2001, 7 p.

Tiktak A., de Nie D., van der Linden T., Kruijne R. (2002) Modelling the Leaching and Drainage of Pesticides in the Netherlands: The GeoPEARL model, Agronomie 22, 373-387.

Tiktak A., van der Linden A.M.A., Merkelbach R.C.M. (1996) Modeling pesticide leaching at a regional scale in the Netherlands. RIVM report No. 715801008, Bilthoven, the Netherlands, 1996.

Weber J.B., Miller C.T. (1989) Organic chemical movement over and through soil, in: Sawhney B.L., Brown K. (Eds.), Reactions and movement of organic chemicals in soil, SSSA Special Publication Number 22. Soil Science Society of America, Inc., American Society of Agronomy, Inc., Madison, Wisconsin, USA, pp. 305-334. 